\title{
Natural Tourism Through The Sensation of Tourists with Visual Impairments
}

\author{
Hanny Hafiar ${ }^{1}$, FX. Ari Agung Prastowo ${ }^{2}$, Centurion C. Priyatna ${ }^{3}$, Evi Novianti ${ }^{4}$ \\ Universitas Padjadjaran ${ }^{1-4}$ \\ \{hannyhafiar@unpad.ac.id $\left.{ }^{1}\right\}$
}

\begin{abstract}
Tourism is an activity traveling to a place that is intended to freshen up both soul and body (refreshing), after struggling for so long with routine activities that are considered tiring. Everyone, including people with visual impairment, needs tourism activities and wants the opportunity to travel. Traveling does not have to be done by traveling to far and expensive places. Traveling can be done by visiting a location that is able to help in order to restore both energy and mind. This study used the descriptive method, and the result showed that There are several stimuli caught by the senses of the ears, nose, and skin felt by tourists with visual impairments as a different sensation when they travel in the mountains. Tourists with visual impairments say that the sound of birds, the splash of water, to the friction of leaves is a sensation that can be heard and enjoyed while doing nature tours to the mountains. The aroma of leaves and soil and fresh air are stimuli that are felt by the sense of smell and produce a feeling of fresh and united with nature. While the rocky contours of the uphill cause the desire to continue climbing up to the highest peak.
\end{abstract}

Keywords: Tourism, Traveling, Mountains

\section{Introduction}

The same thing applies to blind people, as individuals they also want to be able to travel and enjoy the atmosphere in tourist attractions. Unfortunately, not all tourist attractions can accommodate the needs of blind people who have visual impairments. There are several studies that have previously examined tourism and disability, including: management and development of community-based tourism in Thailand [1], potential accessibility of tourists with disabilities in Russia [2], and a research on domestic tourism such as: risk assessment of tourist attractions in Dunia Fantasi Jakarta [3], study of social media accounts for tourism in Bali [4], The management of Papuma Beach in Jember [5], to facilities, vehicle and accessibility in Taman Balekambang tourist sites, Taru Jurug Animal Park and Sriwedari People's Entertainment Park (THR) in Surakarta City [6].

Based on the results of the research it is known how important the provision of facilities and infrastructure that can accommodate the needs of tourists with disabilities. There are various arguments behind the lack of fulfillment of disability rights in tourist attractions. In general, there is a lack of awareness of the equal rights of persons with disabilities to obtain the same public services, so that if there are certain obstacles such as funding, the order of priority in meeting the needs of persons with disabilities is often not on the scaling board. 
In addition, the varied needs of persons with disabilities of various types and categories make it difficult for managers of tourism places to determine the priority scale of management and development. There is research that generally has been able to show the types of needs and expectations of disability tourists with various types of disabilities, one of the data relating to this paper is data that displays the needs and expectations desired by tourists with visual impairment, among others:

Table 1. Important criteria for the convenience of tourist attractions through the experience of tourists with visual impairment

\begin{tabular}{ll}
\hline Important criteria & $\begin{array}{l}\text { Tourists With Visual Impairment } \\
\mathbf{N = 5 4}\end{array}$ \\
\hline Sensitivity and attitude of officers & $53 \%$ \\
Effort/act of acceptance /reception to disability & $16 \%$ \\
The availability of comprehensive information & 0 \\
Ease of communication in public areas (phone, & $2 \%$ \\
Internet, etc.) & $6 \%$ \\
Signpost & $8 \%$ \\
Security & $16 \%$ \\
Building accessibility & \\
\hline
\end{tabular}

Source [7]

However, tourists with visual impairment can still enjoy the sensation of a tourist atmosphere, especially if they visit natural tourist sites. Nature tourism that is often targeted and enthused by tourists with visual impairment is natural mountain tourism and coastal nature tourism. Nature tourism, both mountains, and beaches are attractions that are considered to provide a different atmosphere by tourists with visual impairment. This is because the natural atmosphere that is felt when traveling is considered to provide an atmosphere that is different from the atmosphere in everyday life, compared to the atmosphere of a tour to modern tourist attractions, such as malls or artificial amusement parks.

Whereas for cultural tourism for visually impaired people, especially those who are in the totally blind category, feel that cultural information which is the main information on cultural tourism is an entity that is difficult to reach, not all information contained in cultural attractions is information that provides accessibility for tourists with visual impairment. This is different when compared to the atmosphere in natural attractions, which tend to be without information that must be observed, tourists with visual impairment can still enjoy the natural atmosphere offered to all tourists of various types, both tourists with disabilities and nondisabled.

One of the main elements offered by nature tourism is natural scenery. In principle, natural scenery is a beautiful nature that can be enjoyed by way of being seen or discern visually. For example, the flickering lights of the city at night are seen from the location of mountains which have a certain height and flexibility of visibility, or the bright colors of sunlight that are exposed to seawater during rising and drowning, which are usually awaited by tourists visiting the beach. The beauty of color is one sensation that can only be enjoyed by individuals who do not have obstacles in their sense of sight. 
The sensation which is felt by blind tourists is different from the ordinary people, due to the presence of visual barriers, so that color, shape, and movement are not an entity that can be comprehensively enjoyed by the blind. Therefore, this paper intends to describe the sensation of nature tourism, both mountains, and beaches, through the perspective of blind tourists.

\section{Method}

In the process of collecting data, informal interviews are conducted with a number of tourists with visual impairments who visit mountain nature tourism and coastal tourism. As for the tourists with visual impairments which chosen are those who are categorized totally blind and have blindness since childhood so that the collection of memories which is recorded in their memory are still relatively limited.

Furthermore, the collected data is sorted according to interview guidelines and presented after previous source triangulation has been carried out, namely the answers of one informant are confirmed to other sources to obtain an overview. Furthermore, the answers that have been categorized are arranged into a conclusion.

\section{Results and discussion}

In general, vision barriers experienced by people with visual impairments actually make them rely on and maximize other sensory functions such as the sense of hearing, smell, and touch. This means that the ears, nose, and skin are sensory devices which are relied upon to capture stimuli and feel sensations. This is what significantly distinguishes the sensation of the experience felt by the blind compared to those who can see.

For sighted people, the biggest sensation enjoyed when traveling to the mountains and beaches, is more captured by the senses of sight, such as the green leaves, blue mountains, flowers blooming with various colors, wave movements, boats that sail in the ocean, until the sun rises and sets. The things enjoyed by sighted people certainly cannot be enjoyed fully by people with visual impairments. However, there are a number of things that are offered by natural mountain and beach tourism which can be enjoyed as a sensation by tourists with visual impairments presented in the following table:

Table 2. The sensation felt by people with visual impairments in the total category when doing mountain nature tourism

\begin{tabular}{lll}
\hline Sense & Stimulus & Sensation felt \\
\hline hearing (ear) & $\begin{array}{l}\text { The sound of water sparkling cause calm feeling } \\
\text { (springs/waterfalls), leaves friction } \\
\text { and the sound of birds heard more } \\
\text { clearly }\end{array}$ & \\
& $\begin{array}{l}\text { Relaxing atmosphere and } \\
\text { cheerfulness of other tourists } \\
\text { The air is cleaner and different from } \\
\text { what is felt every day }\end{array}$ & A feeling of freshness \\
& $\begin{array}{l}\text { Leaf and soil aroma } \\
\text { smell (nose) }\end{array}$ & $\begin{array}{l}\text { giving rise to feelings that blend } \\
\text { with nature }\end{array}$
\end{tabular}


Air temperature as an effect of the create a cool impression high mountain terrain

Air pressure as an effect of the high cause a damp impression mountain terrain

Land and rocky roads in the Raising the spirit to keep going mountains and climbing

Source: research data

There are several stimuli caught by the senses of the ears, nose and skin felt by tourists with visual impairments as a different sensation when they travel in the mountains. Tourists with visual impairments say that the sound of birds, the splash of water, to the friction of leaves is a sensation that can be heard and enjoyed while doing nature tours to the mountains. The aroma of leaves and soil and fresh air are stimuli that are felt by the sense of smell and produce a feeling of fresh and united with nature. While the rocky contours of the uphill cause the desire to continue climbing up to the highest peak.

In general, these stimuli are also felt by sighted tourists, but because the sense of sight provides more information, the sensation felt by sighted tourists is to experience the beauty and breadth of nature seen in the mountainous region. That is, there are similarities in stimuli and sensations among blind tourists and sighted tourists, but there are some differences in the effects that are felt so that it affects the differences in the priority scale and the order when answering informal interview questions.

Furthermore, there are data that show the sensations felt by people with visual impairments while doing coastal nature tourism which is presented in the following table:

Table 3. The sensation felt by people with visual impairments in the total category when doing coastal nature tourism

\begin{tabular}{|c|c|c|}
\hline Sense & Stimulus & Sensation felt \\
\hline \multirow[t]{2}{*}{ hearing (ear) } & The sound of the waves & cause a feeling of peace \\
\hline & $\begin{array}{l}\text { Relaxing atmosphere and cheerfulness of } \\
\text { other tourists }\end{array}$ & transmit its own excitement \\
\hline \multirow[t]{2}{*}{ smell (nose) } & $\begin{array}{l}\text { The air is cleaner and different from what } \\
\text { is felt every day }\end{array}$ & $\begin{array}{l}\text { A sensation that is different from the air } \\
\text { that is inhaled every day }\end{array}$ \\
\hline & Fishy aroma of sea water & Arouse hunger \\
\hline \multirow[t]{3}{*}{ touch (skin) } & $\begin{array}{l}\text { Air temperature as an effect of low coastal } \\
\text { plains }\end{array}$ & $\begin{array}{l}\text { cause a hot impression and healthy } \\
\text { sweats }\end{array}$ \\
\hline & $\begin{array}{l}\text { Air pressure as an effect of low coastal } \\
\text { plains }\end{array}$ & $\begin{array}{l}\text { creating a dry impression that } \\
\text { encourages the desire to swim }\end{array}$ \\
\hline & $\begin{array}{l}\text { Beach sand and rocks felt on the soles of } \\
\text { the feet and hands }\end{array}$ & A desire to explore \\
\hline
\end{tabular}

Source: research data

If in the sighted tourists, the first sensation mentioned averages refer to the beauty of the atmosphere of the sunset, sunrise, the vastness of the sea, and the stretch of beach. Whereas for tourists with visual impairments, they tend to mention the sound of the waves which indicate they are close to the beach location. Whereas the scent of the coastal air and the hot air temperature and cause a distinctive hot sensation to occupy the next position. It also shows 
that there are differences in stimuli and sensations that are caught and become the priority of the mention expressed by the speakers.

There is a sensation felt by tourists with visual impairments when they feel the rising contours of mountainous land, namely the emergence of a desire to climb higher, but unfortunately, tourists with visual impairments also realize that in some tourist attractions, the desire to climb, is relatively difficult to realize due to limited facilities such as facilities and safe infrastructure and makes it easy and allows tourists with visual impairments to climb mountains to a certain extent.

Whereas in the present era, tourist attractions have competed to provide Accessible tourism which is defined as an effort to support the ability of disabilities and parents to be able to enjoy products, services, and tourism environments as well as sighted tourists to achieve equality. [8], because tourism is a right for everyone including persons with disabilities [9]. Therefore, there are several efforts in the form of research that seeks to explore the possibility of providing facilities at tourist sites that have accessibility for persons with disabilities [10], as a strategic step in developing tourist attractions that recognize the importance of disability rights.

The thing that has become the fulcrum in this paper is describing how different and limited the sensations that can be felt by people with visual impairments in traveling and enjoying nature tourism compared to sighted people. Plus the opportunity to enjoy such a limited sensation often gets smaller with the limited supporting facilities available in natural attractions for people with disabilities. This is compounded by the behavior of tourists in carrying out tourism in tourist attractions.

One of the factors that influence the attractiveness of tourist areas is the comfort factor [11]. This becomes interesting when a tourist with visual impairments visits a natural tourist spot to enjoy the coolness and freshness of the air in the mountains and beaches, but they are still disturbed by cigarette smoke pollution from other visitors, so the sensation of natural freshness becomes difficult to enjoy. Though the freshness of inhaled air is one of the valuable sensations and can still be enjoyed by their senses who do not experience obstacles.

Obstacles to getting a sensation and enjoy a tourist spot, not only centered on elements of facilities in tourist attractions but also elements of the journey taken to tourist attractions, especially if traveling with family in the holiday season. Although there have been many public policies that have been sought to provide services for persons with disabilities, tourism services for persons with disabilities are still relatively limited [10]. One of them is information about accessibility available in tourist attractions, not yet well publicized. Even though this information is one of the important info and is sought by disability before planning tour itineraries [12].

Traveling to enjoy the sensations offered by natural attractions, is a right that can be enjoyed by everyone, including disabilities, but to travel requires non-routine costs that relatively require careful calculation in planning, especially for persons with disabilities. Therefore, special opportunities such as traveling often cannot be enjoyed and experienced by various causal factors, including financial factors and disability conditions [13]. So that in developing countries including Indonesia, holidays to tourist attractions are a special opportunity for people with disabilities.

As a communal community, Indonesian people feel more comfortable and pleasant when doing tourism activities with their families. So is the case with blind tourists. They will feel more comfortable and feel their own sensations when traveling with family. However, the orientation of changes in public services carried out by tourist attractions tends to be centered on changes in physical facilities and has not yet penetrated the intrapersonal and interpersonal 
aspects as one of the beneficial impacts [10]. Whereas one of the supporting factors that encourage the existence of tourism activities of persons with disabilities and their families, or family tourism activities with members who experience disability is an aspect of service that provides comfort in intrapersonal and interpersonal conditions among family members who travel, as well as relationships with other tourists.

Therefore, there are suggestions raised by visitors that are relevant to the results of previous research as follows: lighting facilities, hygiene conditions, presence of guides, improvement of access roads, improvement in the quality of accessibility information on promotional media, construction of parking lots that consider the needs of persons with disabilities, accessible toilets and places of worship [5]. All of these are expected to further enhance the comfort and optimization of opportunities for persons with disabilities to experience the sensation of nature tourism so that despite experiencing limited vision, they can still travel and obtain their rights to be able to enjoy the nature created by God for the people.

\section{Conclusions}

Based on the findings, it is known that the sensation felt by persons with disabilities when doing tourism to natural attractions in the form of mountains and beaches is relatively the same as that of sighted people. However, there are differences in sensations caused by the limitation of vision, which is unable to enjoy natural beauty which correlates with color, shape, and movement. But with these limitations, blind tourists can actually feel natural sensations in other forms that are sensed by the ears, nose, and skin which on average are not prioritized by alert tourists. This is due to the sense of sight possessed by ordinary tourists dominating the delivery of stimuli so that the sensations that are more common to the sighted tend to be visual.

Therefore, consider that the limitations of sensations felt by blind people, the relevant parties should be able to optimize opportunities for tourism in tourism, so that the limitations of facilities at tourist sites do not further add to the opportunities to enjoy the sensation of natural tourism for persons with visual impairments who certainly have visual limitations.

\section{References}

[1] M. Sripun, S. Yongvanit, and R. Pratt, "Power, Legitimacy, and Urgency of Community-Based Tourism Stakeholders in Northeastern Thailand," Asian Soc. Sci., vol. 13, no. 4, p. 104, 2017.

[2] V. Kourakevitch, "Customers' Expectations Towards Accessible Tourism Services : iCanTrip Oy," Bachelor Thesis, KYAMK Univ. Appl. Sci., no. April, 2016.

[3] I. G. A. A. Yudistira and A. Susanto, "Rancangan Sistem Penilaian Keselamatan Pengunjung Tempat Wisata," Widya, vol. 29, no. 320, pp. 19-24, 2012.

[4] E. A. Surijah, C. T. Kirana, N. P. J. D. Wahyuni, P. C. Yudi, and N. K. B. Astini, "Membedah Instagram: Analisis Isi Media Sosial Pariwisata Bali," Intuisi J. Psikol. Ilm., vol. 9, no. 1, pp. 1-17, 2017.

[5] M. P. Adiati and A. Basalamah, "Kondisi Pariwisata Berkelanjutan Di Bidang Sosial Budaya Berdasar Pengalaman Dan Harapan Pengunjung Di Pantai Tanjung Papuma, Jember," Binus Bus. Rev., vol. 5, no. 1, pp. 80-90, 2014.

[6] R. H. Haryanti and C. Sari, "Aksesibilitas Pariwisata Bagi Difabel di Kota Surakarta ( Studi Evaluasi Peraturan Menteri Pekerjaan Umum Nomor 30 Tahun 2006 Tentang Pedoman Teknis Fasilitas Dan Aksesibilitas Pada Bangunan Gedung Dan 
Lingkungan )," Spirit Publik, vol. 12, no. 1, pp. 85-96, 2017.

[7] O. Moufakkir, "Transformative consumer service: Toward a better tourism enjoyment for tourists with disabilities," Téoros Rev. Rech. en Tour., vol. 32, no. 2, pp. 116-126, 2013.

[8] V. T. Bindu and M. Devi, "Accessible Tourism: Determinants and Constraints; A Demand Side Perspective," IOSR J. Bus. Manag., vol. 18, no. 9, pp. 1-8, 2016.

[9] U. Zakiyah and R. Husein, "Pariwisata Ramah Penyandang Disabilitas: Studi Ketersediaan Fasilitas Dan Aksesibilitas Pariwisata Untuk Disabilitas Di Kota Yogyakarta," J. Ilmu Pemerintah. Kebijak. Publik, vol. 3, no. 3, pp. 483-505, 2016.

[10] W. H. Kong and K. I. Loi, "The barriers to holiday-taking for visually impaired tourists and their families," J. Hosp. Tour. Manag., vol. 32, pp. 99-107, Sep. 2017.

[11] D. Hardoyo, F. Muhammad, and T. Taruna, "Perencanaan Kegiatan Wisata Pendidikan Dalam Kawasan Geopark Rinjani Lombok Berbasis Daya Dukung Lingkungan (Studi Daerah Aik Berik)," J. Ilmu Lingkung., vol. 14, no. 2, pp. 103-107, 2016.

[12] S. N. Hansen, "Accessible Tourism - A Study Of The Role Of Accessibility Information In Tourists ' Decision-Making Process.," Aalborg University Cph, Tourism, 2017.

[13] J. Small and S. Darcy, "Tourism, disability and mobility.," in Tourism and inequality: problems and prospects, no. June 2014, Wallingford: CABI, 2010, pp. 1-20. 